\title{
Information Technology Training For Under-Represented Minority Teachers And Students
}

Ephrem Eyob, (E-mail: eeyob@vsu.edu), Virginia State University Ago Quaye, (E-mail: aquaye@vsu.edu), Virginia State University Emmanuel Omojokun, (E-mail: Emmanuel@vsu.edu), Virginia State University

\begin{abstract}
This paper will present an attempt for addressing the high rate of under-representation of minority students and teachers in Information Technology (IT) in low income localities. It appears that these communities have been left behind during the economic boom of the dot.com experienced by the rest of the western world and the nation. The paper will discuss on strategies to alleviate the disparity between the 'haves' and 'have not' in information technology training, skills, and economic opportunity that can be availed through use of e-commerce and, generally, seeking information through the Internet. Our proposal is to train teachers and students in such communities to make difference in their lives and by mentoring the teachers and hopefully the knowledge passed to the teachers will reach their students in junior and high schools.
\end{abstract}

\section{Introduction}

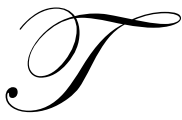

his paper will propose strategies to tackle the low participation of minority students (AfricanAmerican, Hispanic-American, and other members of the minority populations) and their instructional faculty that mostly comes from the same communities in information technology skills. The teachers are mostly from middle and high school, and we believe that training the teachers in IT will enhance the transformation of their students to get motivated to enter the IT workforce. The strategies discussed will enhance the skills, knowledge, and abilities (SKA) of these segments of society by providing the foundation and enabling them for fast entry in IT jobs. Introduction of innovative instructional material based on the state-of-arts technology, student assessment, and delivery methods for the most part empower both the instructional faculty and the students for life long learning skills and gain critical workforce IT skills. According to the National Center for Education Statistics [9],

"Teacher preparation and training to use information technology is a key factor to consider when examining teacher use of computers and the Internet for instructional purposes. In 1999, approximately one-third of teachers reported feeling well prepared or very well prepared to use computers and the Internet for classroom instruction, with less experienced teachers indicating they felt better prepared to use technology than their more experienced colleagues. For many instructional activities, teachers who reported feeling better prepared to use technology were generally more likely to use it than were teachers who indicated that they felt unprepared."

\section{Strategies For Minorities Youth Based Training In It}

The purpose of these types of training is to enhance:

- $\quad$ Increase workforce skills in quantity and quality

- $\quad$ Increase IT literacy and their application to job placements [7]

- $\quad$ Increase computational and quantitative skills of this segment of society [4]

- $\quad$ Enhance the ability to work in teams 
- $\quad$ Learn skills to solve complex problems

- $\quad$ Instill excellent and dependable working habits.

The youth based training schemes are usually short training durations provided during summer sessions and focus exclusively on information technology and IT applications in other disciplines such as mathematics, sciences, business, and other vocational oriented subjects. The main goal is to create innovative ways of delivering of new/old instructional material so they students will have maximum impact on the student's learning motivation [2].

\section{Strategies For Increasing Minorities Teachers In Information Technology}

The instructional activity for teachers has multipurpose:

- $\quad$ Enhance teachers' skills in IT [8]

- $\quad$ Provide opportunities to put in practice on what was learned from the these trainings

- Increase teachers' fluency in the latest IT pedagogy

- Increase and support the learning and teaching for integrating IT in the core curriculum at their respective level of instructions.

- $\quad$ Use of effective grading [7].

The information technology instruction for teachers is also short training sessions either provided during weekends or short summer sessions. Instructional faculty at the middle and high school level are the linchpin in providing IT literacy and expertise for their respective school communities. Some school district teachers have pointed on the paucity of technology - for example, the lack of Internet in their school systems. A study by the National Telecommunication and Information Administration [1] in 2002 found:

“... approximately $85 \%$ of middle and high school student report that they use a computer in school. Home use, however, drops precipitously, from $83 \%$ to $28 \%$, as household income drops. Ethnic differences are also pronounced. For example, home use by Hispanic and Black Americans is just over one-half of what is for Asian, Pacific Islander, and White Americans."

\section{Implementing The Strategies: The Case Of A County \& City}

We have implemented our strategies in area schools in two phases. In the first phase, we trained the trainers (high school teachers) in the city of Petersburg and the counties of Sussex and Chesterfield in south central Virginia. We developed training materials appropriate to the level of sophistication of the participants for credit (three credit-hour) and non-credit technology course based on the interest expressed by the teachers', technology personnel in their respective sites, and our expectations. The non credit training was delivered at the district school site and for the credit-hours training were conducted at our institution for two consecutive semesters. There were eighteen participants (teachers) in the first semester and twenty in the second semester. The non credit workshops had 40 participants of teachers, auxiliary staff, and administrators. The course was fully hands-on and included the following:

- developing workable curriculum in information technology for their classes in the high schools.

- $\quad$ introduction to computer hardware, software, and computer networks

- $\quad$ hands-on experience in advanced productivity applications

- $\quad$ navigating the Internet, exposure to Internet resources, utilizing the Internet for research and for developing IT lesson plans.

- $\quad$ developing web pages

- $\quad$ e-commerce and Internet security awareness

- $\quad$ computer programming, and

- technology transfer 
In the second phase, we met with a high school in the city of Petersburg that was seeking technology teachers. We taught $9^{\text {th }}$ and $10^{\text {th }}$ grades in computer programming and technology courses to mostly minority students for two semesters. Our goal was to help the students to develop their confidence and interest in IT, and to motivate the minority students to plan into majoring in IT disciplines at college. It is interesting to note that at the beginning of the first semester, a survey of the minority students showed that only $8 \%$ of them will major and seek employment in IT. This number increased to $36 \%$ at the end of the second semester.

The Sussex County implementation involved a total of 30 educators. Of these three were administrators, fifteen teachers, six secretaries, five paraprofessionals, and one librarian. All the participants took park in 12 hours of instruction on the use of word-processing (WORD), spreadsheet (EXCEL), presentation (PowerPoint) and database management systems (ACCESS) packages. The group has an average age of 46 years and teaching experience of 12 years. There were four males and twenty six females, three of whom were Caucasians.

Our next step is to develop proposals for IT grants that will enable us to:

- $\quad$ expand our implementation to include teachers and minority students in middle and high schools situated near and far from our locality.

- $\quad$ promote IT literacy and awareness in the minority community

- $\quad$ provide career guidance to minority students and increase course takings by minorities in their pre-college education

- $\quad$ promote increased technology majors by minorities

- $\quad$ track the minority students as they enter and graduate from college

\section{Conclusion}

The holistic approach of teaching instructional faculty and students of the less represented communities, US minorities, via various medium such as the Internet, summer sessions, and short workshops for community based programs provides opportunities for technological and computer competency. Hopefully, such activities will enhance skills of students to continue their education at college level and later gain other job skills that are in much demand by the marketplace for higher paying jobs and lead a future of stable employment opportunities.

\section{References}

1. Cradle, John and Bridgforth (2002). Effective site level planning for technology integration. http://www.wested.org/ techpolicy/plannung.html

2. US Department of Education (June 1992) "Hard Work and High Expectations: Motivating Students to Learn, " http://www.kidsource.com

3. U.S. Department of Education Office of Educational Research and Improvement Programs for Improvement Practices, www.ed.gov/offices/OERI

4. Mallenby, Douglas W. and Mallenby, Michel (2003). " Use of brief Collaborative Quizzes on New Quantitative Lecture Materials," The Decision Sciences Journal of Innovative Education.

5. Silberman, M (1996). Active Learning. Allyn and Bacon, Massachusetts.

6. $\quad$ Slavin, R.E. (1990). Cooperative Learning. Englewood Cliffs, NJ: Prentice Hall.

7. Walwood, B.E., Anderson, V. J. (1996). Effective Grading. Jossey-Bass, San Francisco.

8. Sivin-kachala, Jay and Bialo, Ellen.( 1994). Report on the effectiveness of technology in schools, 19901994. Washington, DC: Software Publishers Association.

9. National Center for Education Statistics (2000), Teachers' Tools for the 21st Century: A Report on Teachers' Use of Technology. NCES 2000-102. Washington, DC: U.S. Department of Education, Office of Educational Research and Improvement 
Notes 